
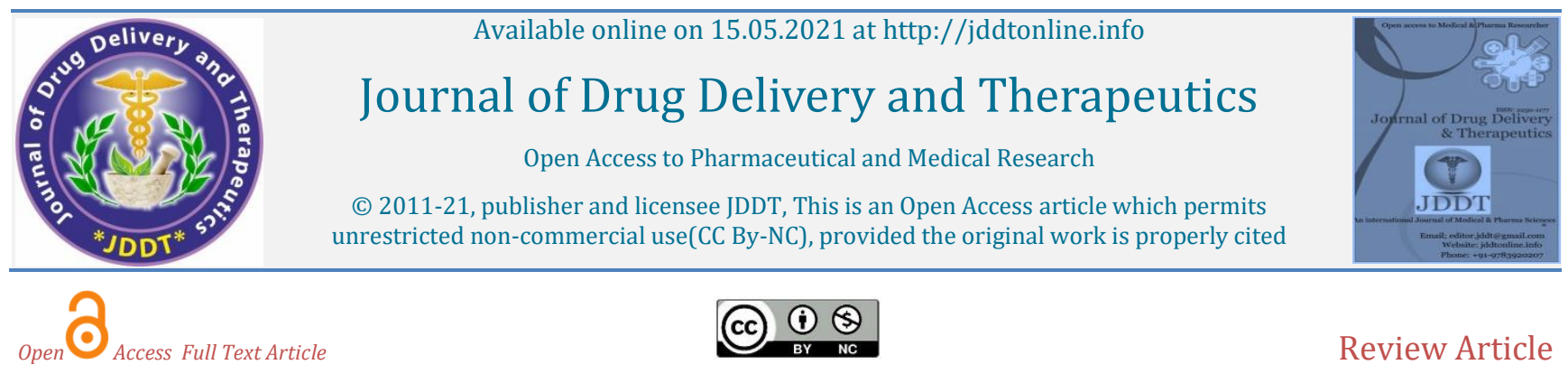

Review Article

\title{
Traditional Uses, Phytochemical and Pharmacological Properties of Ficus auriculata: A Review
}

\author{
Garima Tamta*, Nisha Mehra, S. Tandon \\ Department of Chemistry, Govind Ballabh Pant University of Agriculture and Technology(263145), Pantnagar, Uttarakhand 263145, India
}

\begin{tabular}{ll}
\hline Article Info: \\
\hline$\square$ & Article History: \\
& Received 27 March 2021; \\
& Review Completed 02 May 2021 \\
& Available online 15 May 2021
\end{tabular}

Cite this article as:

Tamta G, Mehra N, Tandon S, Traditional Uses, Phytochemical and Pharmacological Properties of Ficus auriculata: A Review, Journal of Drug Delivery and Therapeutics. 2021; 11(3):163-169

DOI: http://dx.doi.org/10.22270/jddt.v11i3.4853

\section{*Address for Correspondence:}

Garima Tamta, Department of Chemistry, Govind Ballabh Pant University of Agriculture and Technology (263145), Pantnagar, Uttarakhand 263145, India

\begin{abstract}
Ficus auriculata belongs to family Moraceae. It is also known as Elephant earfig tree because of its large leaves. In India it is commonly known as Timla, Gular, Tirmal, Timal, Timbal, Tremal, Trimmal.. The plants are mainly distributed in temperate, tropical and subtropical regions of about $1800-2600 \mathrm{~m}$ altitude. It is native to Asia, especially in India, China, Nepal, Bhutan, Pakistan, Myanmar, Thailand, Vietnam, Malaysia.The plants have great ethnomedicinal importance and are used in traditional folk medicine for curing many ailments in humans. The plants rich in Phytoconstituent e.g. alkaloids, carbohydrates, saponins, glycosides, phytosterols, resins, phenols, tannins, diterpenes, flavonoids, proteins, and amino acids which are present in barks, leaves and fruit extract. The review reveals that huge numbers of phytochemicals which was isolated from the plant possesses the biological and pharmacological properties are shown by the bark, leaves and fruits extract of Ficus auriculata i.e antioxidant, antibacterial, hepatoprotective, histopathological studies, toxicity activity, anticancerous, antidiabatic, hyperlipidemic, hyperglycemic and anti-inflammatory. Leaf extract has also an important role in Glutathione level in cardiac and also used as fodder for farming system, for medicinal properties and for further commercial purpose.
\end{abstract}

Keywords: Ficus auriculata, Phytochemistry, Pharmacological Activity, Herbal Medicine

\section{INTRODUCTION}

According to WHO $80 \%$ of world populations depends on medicinal plants and the rest of population health depends on commercial. About 21,000 species of plants used for their medicinal properties ${ }^{1}$. India has the greatest resources of medicinal herbs endowed with a wide range of agroclimatic conditions and is known as the botanical backyard of the world. India is a biodiversity hotspot and a great variety of fruiting trees are indigenous to this region of the world as confirmed by various reports ${ }^{2}$. Over the centuries, Indian herbal drugs used as a major source of medicines for the treatment and prevention of many diseases. Ethnobotany embraces a complicated relationship between plants, people and way of life. This relationship between flora and human cultures is no longer confined to the use of vegetation for meals, clothing and shelters, but also includes their use for spiritual ceremonies, ornamentation and fitness care ${ }^{3}$. Ficus is a genus that consists of 750 species of medicinal plants primarily occurring in tropical and subtropical regions throughout the world.

There is a large variation in the habitat of this species. Ficus genus belongs to the mulberry family (Moraceae). Fig species are rich in nutrient, vitamins, mineral elements, water, and fats. Figs are rich source of calcium and fiber. According to USDA data for the Mission variety, dried figs are rich in fiber, vitamin $\mathrm{K}$, copper, magnesium, manganese, calcium, potassium ${ }^{4}$. The literature survey reported that figs have been cultivated over 1100 years and these are one of the earliest cultivated plants for human use $\mathrm{e}^{5}$. The genus can be gently reviewed by the very distinguishing syconium and lactory latex and are collectively known as "figs". Ficus plants are used by humans in different ways throughout the tropical and sub-tropical regions. Plants are origin of medication and nutrition and are used as decorative trees, devotional plants, lac hosts, fuel, fodder hedges or enclosures $^{6}$. There is important hereditary diversity among distinct varieties of fig, which contain wonderful pharmacological activities and are of commercial significance. The medicinal plants of the genus Ficus consist of triterpenes, flavonoids, polyphenols, alkaloids, sterols, coumarins and other secondary metabolites ${ }^{7}$.The application of these phytochemicals as anti-rheumatic, mild laxative, antihelminthic, antidiabetic, digestive, anti-dysentery agents and anticoagulant potential have been reported 8 . Investigatation about one of species of Ficus genus i.e Ficus auriculata Lour. belonging to the Moraceae family has got different traditional medicinal uses named as Roxburgh fig, is a type of fig tree which is common in southeast Asia and distinguished for its prodigious circular leaves. Its fresh mature fruits (female syconia) and young purple leaves are used as fodder 9 .

F. auriculata is also an important tree fodder in the Himalayan region of Nepal and India. Its fodder quality is far superior to paddy straw, the main winter fodder in the rice growing regions of the Himalayas. Tree fodders play an 
important role in traditional farming systems common across the foothills of the Himalayas and are especially valuable during the dry winter season ${ }^{10}$.

\section{TAXONOMIC CLASSIFICATION 11 :}

Kingdom: Plantae (Plants)

Subkingdom: Tracheobionta (Vascular plants)

Superdivision: Spermatophyta (Seed plants)
Division: Magnoliophyta (Flowering plants)

Class: Magnoliopsida (Dicotyledons)

Order: Urticales

Family: Moraceae (Mulberry family)

Genus: Ficus L. (Fig)

Species: F. auriculata Lour.

Synonyms: F. roxburghii Wall

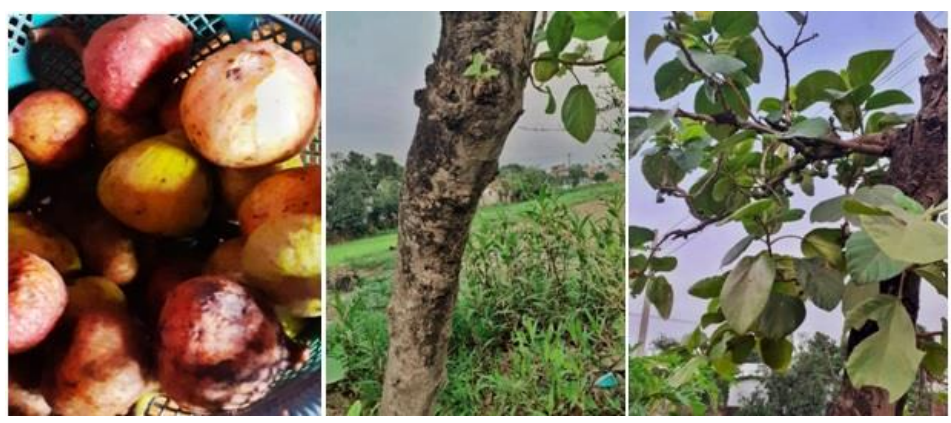

Figure 1: fruits, bark and leaves of Ficus auriculata

\section{COMMON INDIAN NAMES:}

Gular, Timbal, Timal, Timla, Tirmal, Tremal, Trimmal 11

Habitat: Ficus, the fig genus, consists of over 800 species and is one of about 40 genera of the mulberry family. The plants are mainly distributed in temperate, tropical and subtropical regions of about $1800-2600 \mathrm{~m}$ altitude. It is native to Asia, especially in India, China, Nepal, Bhutan, Pakistan, Myanmar, Thailand, Vietnam, Malaysia etc. It is present in most tropical and subtropical forests. Distribution over India ranges from sub Himalayan region and in the deciduous forest of Deccan and South India ${ }^{12}$.

Botanical description: F.auriculata is also known as Elephant earfig tree because of its large leaves, young leaves start with intense red colour and then turn into more green colour when it reach to their large size. The tree is a very large evergreen, 4-10 $\mathrm{m}$ tall, with huge spreading limbs supported by aerial roots which later form accessory trunks extending to a large area. The bark is greyish brown with rough texture. Leaves are simple, 5-8 cm long, 5-12.5 cm broad, oval, ovate or orbicular-ovate to oblong, petioles 1.2$5 \mathrm{~cm}$ long, stipules are $1.5-2 \mathrm{~cm}$. Fruits have fleshy pericarp and pear shaped with 8-12 conspicuous longitudinal ridges, $3-5 \mathrm{~cm}$ in diameter and with achenes embedded in them, riped fruit is dark red in colour ${ }^{11}$.

\section{TRADITIONAL USES:}

Leaves of Fauriculata are crushed and the paste is applied to the wounds. They are also used in diarrhoea and dysentery. It's stem bark juice is effective for cuts and wounds and diarrhoea,. Roasted figs are taken for diarrhoea and dysentery. Latex of roots is used in diarrhea, cholera mumps , and vomiting. Mixture of root powder of F. auriculata and bark of Oroxylum indicum is taken in jaundice ${ }^{13}$. Ethnic people in kharagchari hill district use F. auriculata as food and medicinal plant ${ }^{14}$.

Fruits of Ficus auriculata are very tasty. Ficus species are rich in flavonoids, polyphenolic compounds, which have strong antioxidant properties that help in prevention and treatment of various oxidative stress related diseases such as and hepatic and neurodegenerative diseases. The paste of leaves is applied on the wounds for curing15.

Many Ficus species are usually used in regular treatments to remedy various diseases. They have been used as traditional remedy as stomachic ,astringents, vermicides, antihelmintics ,carminatives, hypotensives and antidysentery drugs. Many species are grown for shade and ornament in gardens. Various species produce edible figs of various palatability. All species possess latex-like material within their vasculatures that grant protection and self restoration from bodily assaults ${ }^{16}$.

\section{PHYTOCHEMISTRY :}

Phytochemical screening of F.auriculata leaf and fruit extract were evaluated. Which showed the presence of phenols, flavonoids, glycosides, resins, tannins. Alkaloids are absent ${ }^{17}$.F. auriculata leaf extracts revealed the presence of carbohydrates, phenols, tannins, flavonoids, terpenoids, and alkaloids. Glycosides were present in methanol extract and absent in chloroform extract, while saponins were absent in both extracts of leaf 18 . Phenolic compounds showing wide bioactivity including antioxidant properties. Total phenolic content was found to be $21.404 \mathrm{mg} \mathrm{GAE} / \mathrm{mg}$ dry weight and total flavonoid content was found to be $50.83 \pm 1.32 \mathrm{mg}$ GAE/mg dry weight in leaves of Ficus auriculata ${ }^{19}$. F. auriculata phytochemical composition and biological potentials were evaluated. The total phenolic and polyphenolic contents were determined by Follin Ciocalteu reagents method. The total phenolic acid content was found to be $5.75 \mathrm{mg} / \mathrm{g}$ while total polyphenolics $6.14 \mathrm{mg} / \mathrm{g}$. The presence of quercetin, epigallocatechin with concentrations 3.79 and $4.64 \mathrm{mg} / 100 \mathrm{~g}^{20}$. Phytochemical constituents were estimated in F.auriculata or F.roxburghii such as total phenols, total flavonoid, anthocyanin, ascorbic acid and total carotenoid The total phenol content was estimated to be $4.13 \mathrm{mg} \mathrm{GAE} / \mathrm{g}$, total flavonoid was $3.10 \mathrm{mg} \mathrm{QE} / \mathrm{g}$. Ascorbic acid, anthocyanin and total carotenoid values were estimated in a range of $3.36 \mathrm{mg} / 100 \mathrm{~g}, 1.13 \mathrm{mg} / 100 \mathrm{~g}$ and $0.68 \mathrm{mg} / 100 \mathrm{~g} 21$. Phytochemical analysis of stem bark extracts of Ficus auriculata showed the presence of fatty oils, alkaloids, carbohydrates, saponins, glycosides, phytosterols, resins, phenols, tannins, diterpenes, flavonoids, proteins 
and amino acids ${ }^{22}$. Eight carbon compounds were isolated including betulinic acid, lupeol, stigmasterol, bergapten, scopoletin, $\beta$-sterol-3-0- $\beta$-D-glucopyranoside, myricetin and quercetin-3-0- $\beta$-D-glucopyranoside from leaves and fruits of F.auriculata ${ }^{23}$. Fatty acid profiling in F.auriculata fruit by GC-MS analysis with $1.76 \%$ of fatty oil extraction from nonpolar solvent that showed the presence of stearic acid, palmitic acid, oleic acid, linoleic, linolenic acid, 3-hydroxy lauric acid and vaccenic acid. The main oil components were analysed, i.e. unsaturated fatty acid, linolenic acid , linoleic acid has a massive curative and health preventive properties. Saturated fatty acids were found i.e. palmitic acid and stearic acid in the oil that has huge industrial applications 22 .

New isoflavon was isolated from F.auriculata roots i.e (1) 5,7,4'-trihydroxy-3'-hydroxymethylisoflavone with three other known isoflavon compounds, i.e. (2) $3^{\prime}$-formyl-5,4'dihydroxy-7-methoxyisoflavon, (3) ficuisoflavone and (4) alpinumisoflavone. (1) isoflavonoe containing 12 carbon atom which was elucidated by NMR and MS spectroscopic techniques and other three were identified by comparing with reports in a literature ${ }^{24}$.

Nine phytochemical constituents were analysed by HPTLC in the leaf extract of F.auriculata and most of them showed orange red fluorescene at $366 \mathrm{~nm}$ and the basic characteristics of polyphenols, flavonoids such as anthocyanin is fluorescence and possess antioxidant property similar to standard quercetin. The presence of about thirteen components in the sample characterized by UPLC with different retention time. With the help of MS/MS spectra and fragmentation pattern. Presence of rutin, which is a potent antioxidant has been confirmed by comparing the fragmentation pattern. Rutin(quercetin-3-rhamnosyl glucoside),is a low molecular weight polyphenolic compound that is widely distributed in vegetables and fruits 25 .

Isolation of new 12-membered lactones, ficusine D (1) (3R,4R)-4-hydroxy-de-0-methyllasiodiplodin isolated from stems along with six other known compounds i.e (2) (3R,4R)-4-hydroxymellein , (3) (3S,4R)-4-hydroxymellein, (4) shoreaphenol, (5) heimiol A, (6) (+)-balanocarpol, (7) (+)-ampelopsin 26 .

GC-MS analysis of volatile oil from leaves of F.auriculata extracted by stem distillation . 28 components were identified. Main components were 4 phenyl methyl pyridine $(25.07 \%)$, dibutyl phthalate (17.26\%), phytol(11.58\%) and 3ß-lup-20(29)-en-3-olacetate $(9.20 \%)^{27}$.

Total flavonoid and total phenolic content in F.auriculata leaves were analysed. The results revealed that total phenolic content of the methanol extract of F.auriculata was $83.5 \pm 0.9 \mathrm{mgGAE} / \mathrm{g}$ in $\mathrm{n}$-hexane fraction of plant extract were found $32.1 \pm 1 \mathrm{mgGAE} / \mathrm{g}$ while in ethylacetate fraction were found $77.5 \pm 1.6 \mathrm{mgGAE} / \mathrm{g}$ respectively.Total flavonoid content were investigated in F.auriculata range $(7.35 \pm 0.44$ $\mathrm{mgRE} / \mathrm{g})$ in $\mathrm{n}$-hexane fraction range $(7.05 \pm 0.32 \mathrm{mgRE} / \mathrm{g})$ in ethylacetae and chloroform extract value of flavonoids content were significantly higher ${ }^{8}$.

Fractionation of the extracts of the stems of $F$. auriculata in different solvents i.e, petroleum ether, chloroform and EtOAc gave the isolation of five new 12-membered lactones (1) $(3 \mathrm{R}, 4 \mathrm{R})-4$-hydroxy-de-O-methyllasiodiplodin, (2) 6oxolasiodiplodin and (3-5) are ficusines along with three known related compounds (6-8). The structures of the new compounds were elucidated by spectroscopic method. Compounds 3-5 compounds structure analogue with first 12-membered lactones along with a quinone ring unit. These all compounds have a proliferation function in a primary osteoblast 28 .

Nutritional value: The nutritional value of fruits of F.auriculata may vary from region to region and it is a good source of nutrients including proteins, carbohydrates, and lipids etc. Nutritional values mentioned in the Table 1 17,14

Table 1: Nutritional value of fruits of F.auriculata

\begin{tabular}{|c|c|c|}
\hline Values & \multicolumn{2}{|c|}{ Fruits of F.auriculata } \\
\hline & Saklani et al., 2012 & Khatun et al.,2016) \\
\hline Moisture \% & 46.64 & 3.50 \\
\hline Ash \% & 3.9 & 1.71 \\
\hline Total protein & 5.32 & - \\
\hline Crude fat & 0.65 & 13.13 \\
\hline Crude fibre & 16.96 & - \\
\hline Starch \% & - & 27.09 \\
\hline Organic matter & 96.30 & 5.48 \\
\hline Soluble carbohydrate & - & 135.51 \\
\hline Vitamin C(mg) & 0.09 & 898.0 \\
\hline Energy & - & - \\
\hline
\end{tabular}




\section{PHARMACOLOGICAL ACTIVITIES:}

\section{Antioxidant activity:}

The antioxidant activities of F.auriculata fruits, leaves, bark were determined by using radical scavenging activities. Antioxidant activity of stem bark (FASB) of F.auriculata was investigated by DPPH free radical scavenging method in different polarity solvents namely hexane, chloroform and methanol. At $0.1 \mathrm{mg} / \mathrm{ml}$ scavenging activity of $84.088 \%$ was found in methanol extract, $83.864 \%$ in chloroform extract However free radical scavenging activity of hexane extract was $42 \% 12$.

The DPPH method allows estimation of hydrogen radical donating ability of the extract and result was expressed in EC50. EC50 values were found to be $251.33 \mathrm{mg} / \mathrm{ml}$ for Ficus auriculata and $486 \mathrm{mg} / \mathrm{ml}$ for standard Ascorbic acid respectively. Reducing Power Assay (RPA) was found to be $53.40 \pm 0.01 \mathrm{mg} / \mathrm{ml}$. Reducing capacity of the extract is some other important indicator of antioxidant activity ${ }^{19}$.

F. auriculata methanol and chloroform leaf extract evaluated by DPPH radical scavenging assay as its antioxidant activity, The percentage of radical scavenging was increased with increase in concentration (20-100) $\mu \mathrm{g} / \mathrm{ml}$ ). The highest antioxidant potential was reported in methanolic leaf extract of F.auriculata and its $\mathrm{IC}_{50}$ values lie in the range of $(40-60 \mu \mathrm{g} / \mathrm{ml})$. The antioxidant potential of the extract is due to presence of flavonoids and phenolic content ${ }^{18}$

The antioxidant properties of F.auriculata tips, leaves, inflorescence (syconium), immature fruits and mature fruits were examined by DPPH and ABTS radical scavenging assays, results showed higher antioxidant activity in leaves with $\mathrm{IC}_{50}$ value in the range of $12.47 \pm 0.04$ to $33.43 \pm 1.09$ $\mu \mathrm{g} / \mathrm{ml}$ and also showed ABTS radical scavenging assay (100.36-383.29 mg TEAC g/extract ${ }^{29}$.

The antioxidant activity of ethanolic extract of F.auriculata leaves and fruits was assayed by using DPPH radical. The result revealed that concentration from $2-8 \mathrm{mg} / \mathrm{ml}$ for both leaves and fruits. With increasing the concentrations of the extract antioxidant effect increased. The percentage of DPPH of leaves and fruits from (40.78-85.49) and (44.90-88.24) in a dose dependant manner and the fruit extract has more antioxidant activity than the leaves ${ }^{23}$.

\section{Antibacterial activity:}

Alcoholic extracts of leaves and fruits of F.auriculata were taken at different concentrations $(50 \mu \mathrm{g} / \mathrm{ml}$ to $250 \mu \mathrm{g} / \mathrm{ml})$ and tested against human pathogenic bacterias i.e. Staphylococcus aureus, Esherichia coli, Bacillus aureus, Bacillus subtilis and Pseudomonas aeruginosa. Leaves extract showed the higher inhibition zone in Staphylococcus aureus at concentration $50 \mu \mathrm{g} / \mathrm{ml}$ to $250 \mu \mathrm{g} / \mathrm{ml}(10-21 \mu \mathrm{mm})$, alcoholic extract of fruits showed the higher inhibition zone in Bacillus subtilis at concentration $50 \mu \mathrm{g} / \mathrm{ml}$ to 250 $\mu \mathrm{g} / \mathrm{ml}(9-19 \mathrm{~mm})$. The inhibition zones were less than those as compared to standard drug. The extracts of leaves has more antibacterial activities than fruits extract ${ }^{[23}$.

Antibacterial activity of F.auriculata was investigated by the agar well diffusion method. Hexane, chloroform and methanol extracts of F.auriculata stem bark was tested against two bacterial strains E. coli and S. aureus. Methanolic extract has the greater zone of inhibition $(4.5 \pm 0.5 \mathrm{~mm})$ for E. coli than that of hexane and chloroform extract. In case of $S$. aureus greater zone of inhibition shown by the hexane $(7.1 \pm 1.2 \mathrm{~mm})$ than that of chloroform extract, whereas least antibacterial activity shown by methanolic extract. The
Antibacterial potential of the extracts was very low as compared to the standard antibiotics ${ }^{12}$.

Ethanolic fruit extracts of F.auriculata showed significant activity against food poisoning bacteria Shigella flexneri, Escherichia coli and Staphylococcus epidermidis respective ${ }^{17}$.

Water/ethanol extracts of young and mature leaves of F.auriculate were able to inhibit bacteria, i.e.Escherichia coli, Salmonella enteritidis, Staphylococcus aureus and Listeria monocytogenes. MICs were in the range of 21.60-90.32 $\mu \mathrm{g} / \mathrm{ml}$ for the Escherichia coli, $21.60-188.85 \mu \mathrm{g} / \mathrm{ml}$ or the Salmonella enteritidis, 64.22-188.85 $\mu \mathrm{g} / \mathrm{ml}$ for the Staphylococcus aureus and 76.31-87.82 $\mu \mathrm{g} / \mathrm{ml}$ for the Listeria monocytogenes ${ }^{30}$.

Methanol and chloroform leaf extracts of Ficus auriculata inhibited the growth of E.coli and S. typhimurium. Methanolic extract showed highest zone of inhibition against E. coli, i.e. $18.33 \pm 0.67 \mathrm{~mm}^{18}$. The methanolic leaves extract of $F$. auriculata showed greater potential of antimicrobial activity. Maximum antibacterial potential was observed against $S$. aerus with zone of inhibition $18.3 \mathrm{~mm}^{31}$. F.auriculata leaves extracted in four different solvents i.e. petroleum ether, chloroform, methanol and water that showed the antibacterial activity against pathogenic bacteria (S.aureus, E.coli and P.aeruginosa). In petroleum ether, chloroform, methanol and water leaves extract showed the zone of inhibition (14.3 mm, $14.9 \mathrm{~mm}, 18.3 \mathrm{~mm}$ and $9.1 \mathrm{~mm}$ ) against A.flavus, (13.3 mm, $12.9 \mathrm{~mm}, 13.9 \mathrm{~mm}$ and $8.9 \mathrm{~mm})$ zone of inhibition against F.solani, $(12.9 \mathrm{~mm}, 13.1 \mathrm{~mm}, 18.1 \mathrm{~mm}$ and $10.4 \mathrm{~mm}$ ) zone of inhibition against C.albicans. So results revealed that methanolic leaves extract showed the maximum antibacterial potential with maximum zone of inhibition against C.albicans. ${ }^{33}$.

Isoflavones which were identified in the roots of F.auriculata i.e, (1) 5,7,4'-trihydroxy-3'-hydroxymethylisoflavone (new compound),(2) methoxyisoflavon,(3) 3 '-formyl-5,4'-dihydroxy-7ficuisoflavone and (4) alpinumisoflavone has shown the antibacterial activities against terrestrial pathogenic bacteria i.e. M. tetragenus, B.cereus B.subtilis, S.aureus and S.lutea with MIC range from 1.30-39.93 $\mu \mathrm{M}$ which has inhibition diameter greater than $10 \mathrm{~mm}$. (1) isoflavon shows the effective MIC $-1.30 \mu \mathrm{M}$ against S.aureus., (2) shows the effective MIC-2.49 $\mu \mathrm{M}$ against $M$. tetragenus, ,(3) shows the effective MIC-2.20 $\mu \mathrm{M}$ against B.cereus and S.aureus and (4) shows the effective MIC-4.64 $\mu \mathrm{M}$ against B.subtilis ${ }^{24}$.

\section{Green synthesis of silver nanoparticle:}

Silver nano particle were synthesized by silver nitrate using Leaf extract of F.auriculata. AgNPs showed much significant reduction in the luminance (RLU) of Photobacterium leiognathi compared to the negative blank solution, which was devoid of silver nanoparticles. Nanoparticle solution at a concentration of $200 \mu \mathrm{g} / \mathrm{ml}$, a luminescence of $63 \mathrm{RLU}$, while that of blank was 8927 RLU. The antimicrobial activity of silver nanoparticle can be exploited for wound dressings, ointments, water treatment and different applications such as implant coatings. HPTLC fingerprinting and further UPLCQ-TOF mass spectroscopy analysis showed the presence of the flavonoid glycoside, rutin in the leaf extract. Nano particles from the leaf extract showed good antioxidant potential in DPPH model. SEM and TEM analysis showed that the nanoparticles morphologies were elucidated with an average size of $19-21 \mathrm{~nm}^{25}$.

\section{Anticancer activity:}

Anti-cancerous activity of the chloroform and methanol extracts of $F$. auriculata were estimated by Cytotoxicity 
assay-MTT(in vivo). A549 cells of Lung carcinoma, A549 (1 x 104) were seeded in plates and treated with plants extract. Vincristine sulfate used as positive control and DMSO as negative control. The optical density of each was measured at $595 \mathrm{~nm}$. The A549 cancerous cells were treated with the leaf extract of $F$. auriculata $(100 \mu \mathrm{g} / \mathrm{mL} \mathrm{w} / \mathrm{v})$. There was no significant cancer cell killing activity observed ${ }^{18}$.

Polyamines were investigated in F. auriculata by using MTT assay and the polyamines contents and intracellular content were quantified by using High Performance Liquid Chromatography (HPLC). Results showed the low level of polyamines in F. auriculata $(39.28 \mathrm{nmol} / \mathrm{g})$. Low level of polyamines was found and have an antiproliferative effect against A549 cells ${ }^{32}$.

Cell growth Inhibition by F.auriculata was investigated and additionally effects of its exposure on cell cycle profile through the use of flow cytometer. The model of this study A549 cell line of human lung adenocarcinoma was selected. Results revealed that G1 phase has the highest percentage $(59.7 \pm 1.4 \%)$ as compared to other cell cycle phases, G2/M $(25.4 \pm 0.7 \%), \mathrm{S}(14.6 \pm 1.9 \%)$ and Sub G1 $(0.2 \pm 0.2 \%)$. Therefore, significant decreased of A549 cells in G0/G1 and concurrent accumulation of cells in G2/M phase. Analysis of Cell death revealed significant late apoptosis induced by $F$. auriculata 33

The $80 \%$ ethanolic extract of F.auriculata leaves was screened for cytotoxic activity against human hepatocellular carcinoma (HepG2). Human colon and adenocarcinoma (HT29) cells by MTT assay and determined $50 \%$ of cytotoxic activity concentration (CC50). Apoptotic cell death was observed by inverted microscopy and DNA fragmentation by using agarose gel electrophoresis, the results found the cytotoxicity percent of cell proliferation for HT-29 and HepG2 cell lines in F.auriculata extract at 2,000 $\mu \mathrm{g} / \mathrm{ml}$ and mitomycin $C$ at $50 \mu \mathrm{g} / \mathrm{ml} 31.02 \pm 2.11$ and $30.56 \pm 7.04$ respectively. Plant extracts did not show stronger anticancer activity than the positive control ${ }^{34}$.

\section{Antidiabatic activity:}

The four extracts of F.auriculata fruits i.e. n-butanol (BuOH), ethylacetate (EtOAc), methanol $(\mathrm{MeOH})$ and water (aqueous) was examined at different concentrations (50$500 \mathrm{~g} / \mathrm{mL}$ ). Extract fractions were subjected to $\alpha$-amylase and $\alpha$-glucosidase inhibitory activity and percentage inhibition. The $\mathrm{BuOH}, \mathrm{EtOAc}, \mathrm{MeOH}$ and aqueous fractions recorded respectively 58.39, 78.98, 91.45, and $75.25 \%$ inhibitory activities against $\alpha$-amylase and 66.37, 84.66, 97.75 , and $79.55 \%$ respectively against $\alpha$-glucosidase at a concentration of $500 \mu \mathrm{g} / \mathrm{ml}$. Among all, the methanol fraction recorded the maximum $\alpha$-amylase and $\alpha$ glucosidase inhibitory activity with an IC50 value of 161.730 .43 and $103.430 .67 \mathrm{~g} / \mathrm{ml}$ respectively. F. auriculata fruits could be beneficially used in the treatment of Type 2 Diabetes mellitus ${ }^{22}$.

Ethanolic extracts of $F$. auriculata in diabetic rats induced $8.2 \%$ reduction of blood glucose level as compared to before treatment of diabatic mice.. Diamicron used as a standard that induced $39.8 \%$ reduction of blood glucose level in a diabetic rats ${ }^{23}$.

Diabetes mellitus is a metabolic disorder resulting in hyperglycemia. It can be due to heredity, poor diet, obesity, indigestion, modern lifestyle, mental illness, physical stress, infection in pancreas, hypertension, lipoproteins, less glucose utilization and various other factors. F.auriculata have antidiabetic activity with the fact by taking different concentration of F.auriculata bark aqueous extract(10-100 $\mu \mathrm{g} / \mathrm{ml}$ ) that the plant posses the inhibitory activity on ISSN: 2250-1177 salivary amylase and the percent of inhibition of $F$. auriculata aqueous extract and Acarbose at $595 \mathrm{~nm}$. In results percent of inhibition was ranged from $(4.5-31.3 \%)^{36]}$.

\section{Antiyperglycemic activity:}

The animals with hyperglycemia when administered with methanolic leaf extract of F.auriculata it was observed that decrease in blood glucose level for long term 15 days with doses of 300 and $600 \mathrm{mg} / \mathrm{kg}$ concentrations. In normal control mice slightly increase in body weight. In streptozotocin-induced diabetic mice, there was decrease in body weight from the initial day to 15 day when treated with $300 \mathrm{mg} / \mathrm{kg}$ body weight of methanolic leaves extract (28.97 g-26.84 g) and $600 \mathrm{mg} / \mathrm{kg}$ body weight (27.4 g-26.89 g). Also observed that decrease in a blood glucose level from the initial day to $15^{\text {th }}$ day when treated with $300 \mathrm{mg} / \mathrm{kg}$ body weight of methanolic leaves extract were found to be $(279 \pm 5.0-140.25 \pm 18 \mathrm{mg} / \mathrm{dl})$ and for $600 \mathrm{mg} / \mathrm{kg}$ body weight ( $275.5 \pm 7.2$ to $136.75 \pm 7.4 \mathrm{mg} / \mathrm{dl})$. So, they concluded that a reduction in blood glucose level when streptozotocininduced diabetic mice treated with $300 \mathrm{mg} / \mathrm{kg}$ and 600 $\mathrm{mg} / \mathrm{kg}$ body weight of leaf extract, $49.73 \%$ and $50.36 \%$ reduction and this effect is hypoglycemia. Now this hypoglycemic effect compared with standard glibenclaimide, which is a hypoglycemic agent at $10 \mathrm{mg} / \mathrm{kg}$ body weight, $60.82 \%$ fall was found 35 .

\section{Antihyperlipdemic activity:}

In streptozotocin-induced diabatic mice show the antihyperlipidemic activity. on administration of methanolic leaf extract causes the significant reduction after 15 days in serum level of total cholesterol, LDL-C(low density lipoprotein), VLDL-C(very low density lipoprotein), triglycerides and HDL-C(high density lipoprotein). There was increase in the level of protein in serum of streptozotocin-induced diabatic mice when treated with methanolic leaves extract of F.auriculata at different doses $300 \mathrm{mg} / \mathrm{kg}$ and $600 \mathrm{mg} / \mathrm{kg}$ body weight it was found to be $(4.8 \pm 0.26$ to $4.96 \pm 0.15 \quad \mathrm{mg} / \mathrm{dl})$, serum cholesterol $(167.07 \pm 11.77$ to $168.58 \pm 5.12 \mathrm{mg} / \mathrm{dl})$, serum triglycerides $(106.99 \pm 12.42$ to $117.48 \pm 6.69 \mathrm{mg} / \mathrm{dl})$, serum LDL-C(102.60 \pm 16.66 to $110.92 \pm 8.13 \mathrm{mg} / \mathrm{dl})$, serum VLDL$\mathrm{C}(21.39 \pm 2.47$ to $23.49 \pm 1.33 \mathrm{mg} / \mathrm{dl})$ but there was decrease in a level of serum HDL-C(25.78 \pm 3.34 to $30.06 \pm 1.93 \mathrm{mg} / \mathrm{dl})$ as compard to the normal mice which was found to be $(31.62 \pm 2.03 \mathrm{mg} / \mathrm{dl})$. So that treatment by methanol leaf extract of $F$. auriculata may additionally able to improve the fatty acid impairment metabolism in diabetes. The methanolic leaf extract of $F$. auriculata elevate the secretion of insulin from b-cells of the pancreas, this increased secretion of insulin that stimulates fatty acid biosynthesis ${ }^{35}$.

\section{Antifungal activity:}

Antifungal activity of F.auriculata fruit extract against three fungal strain i.e. Candida albicans, Aspergillus flavos and Aspergillus parasiticus in different solvent fractions (petroleum ether, chloroform, ethyl acetate, ethanol and water) were analysed at different concentrations $(10 \mathrm{mg} / \mathrm{ml}$ and $50 \mathrm{mg} / \mathrm{ml}$ ). Each extract was applied and zone of inhibition was observed at $50 \mathrm{mg} / \mathrm{ml}$ for Candida albicans (ethyl acetate-7 $\mathrm{mm} \pm 1$ ),(acetone-8 $\mathrm{mm} \pm 1$ ),(ethanol-7 mm \pm 1 )and (water-8 $\mathrm{mm} \pm 1$ ), for Aspergillus flavos (ethanol-9 $\mathrm{mm} \pm 1$ ) and (water-7 $\mathrm{mm} \pm 1$ ) and for Aspergillus parasiticus (acetone-7 $\mathrm{mm} \pm 1$ ),(ethanol-8 $\mathrm{mm} \pm 1$ ) and (water-8 $\mathrm{mm} \pm 1$ ). There was no significant inhibitory zones were found ${ }^{17}$.

F.auriculata leaves extract has a antifungal properties against fungal strains(A.flavus, F.solani and C.albicans) which are resistant to leaves extract of F.auriculata in different solvents. In chloroform, petroleum ether, methanol and 
water leaves extract showed the zone of inhibition (15.9 $\mathrm{mm}, 15.1 \mathrm{~mm}, 17.1 \mathrm{~mm}$ and $11.8 \mathrm{~mm})$ against $A$. flavus, $(15.0$ $\mathrm{mm}, 14.7 \mathrm{~mm}, 16.9 \mathrm{~mm}$ and $10.2 \mathrm{~mm}$ ) zone of inhibition against F.solani, $(17.6 \mathrm{~mm}, 16.6 \mathrm{~mm}, 19.8 \mathrm{~mm}$ and $10.6 \mathrm{~mm})$ zone of inhibition against C.albicans. So results revealed that methanolic leaves extract showed the maximum zone of inhibition against C.albicans ${ }^{33}$.

\section{Hepatoprotective activity:}

Animals treated with toxic doses of carbon tetrachloride that cause oxidative damage and liver damage by increase in level of serum enzymes, i.e. SGOT(serum glutamate oxaloacetate transaminase), SGPT (serum glutamate pyruvate transaminase) and ALP(serum alkaline phosphatase). The pretreatment of methanolic and aqueous extract of F.auriculata reduced the elevation of serum enzymes. Methanolic and aqueous extract of F.auriculata at different doses when orally administered to $\mathrm{CCl}_{4}$ - induced hepatoxic mice $(1 \mathrm{ml} / \mathrm{kg})$. The doses that had taken 200 $\mathrm{mg} / \mathrm{kg}$ and $400 \mathrm{mg} / \mathrm{kg}$ for both methanolic and aqueous extract served to test hepatoprotective test for 9 days. It showed the significant decrease in level of serum enzymes. At $200 \mathrm{mg} / \mathrm{kg}$ to $400 \mathrm{mg} / \mathrm{kg}$ body weight for F.auriculata aqueous extract causes reduction in), SGPT(217.6 to 122.79 IU/L), SGOT(312.27 to 227.52 IU/L, ALP(279.3 to 232.33 $\mathrm{IU} / \mathrm{L}$ ) and billirubin (1.23 to $1.19 \mathrm{mg} / \mathrm{dl}$ ). For methanolic extract of F.auriculata at $200 \mathrm{mg} / \mathrm{kg}$ values of SGOT(334.06 IU/L),SGPT(229.40 IU/L), ALP(291.76 IU/L) and bilirubin $(1.2 \mathrm{mg} / \mathrm{dl})$. The liver sections of the mice treated with the crude extracts indicate the moderate improvement with mild vacuolization of hepatocytes ${ }^{39}$.

According to Fishawy et al.,2011, $0.2 \mathrm{ml} / \mathrm{kg}$ p.o ('p.o' i.e. 'per $o s^{\prime}$ or by mouth) of $\mathrm{CCl}_{4}$ causes the hepatoxicity in group of mice. Alcoholic crude extract of $F$. auriculata leaves and fruits when administered to mice orally with a dose 800 $\mathrm{mg} / \mathrm{kg}$ and $\mathrm{CCl}_{4}$ were administered for 5 days. animals died on $6^{\text {th }}$ day. Blood was collected of each animals and determined the serum levels, i.e. AST ( aspartate transaminase ) and ALT(alanine aminotransferase ) enzymes. A group of mice that was administered with $\mathrm{CCl}_{4}$ (positive group) showed the elevation of enzymes i.e. AST (116.75 U/ml) and ALT(94.5 U/ml ), for olive oil (negative group) AST(39.75 U/ml ) and ALT(28.5 U/ml), for alcoholic leaves extract AST (107.5 U/ml ) and ALT(81.5 $\mathrm{U} / \mathrm{ml}$ ) and for alcoholic fruit extract AST (109.25 U/ml) and $\operatorname{ALT}(85.25 \mathrm{U} / \mathrm{ml})$ was found ${ }^{23}$.

\section{Anticoagulant activity :}

The effect of methanolic extract of F.auriculata leaves on haemostasis was evaluated using their anticoagulant potential through prothrombin time (PT) and the activated partial thromboplastin time(APTT) measurements. The prothrombin time of methanolic crude extract of F.auriculata leaves was $26.7 \pm 2.2 \mathrm{~s}$. for $\mathrm{n}$-hexane fraction ranged from $17.3 \pm 0.9$ to $21.0 \pm 1.0 \mathrm{~s}$, for chloroform fraction ranged from $17.7 \pm 0.7$ to $22.0 \pm 1.1$ and for ethyl acetate ranged from $17.8 \pm 0.9$ to $24.0 \pm 1.5 \mathrm{~s}$, respectively. Ethyl acetate fraction of $F$. auriculata had the highest prothrombin time of $24.0 \pm 1.5 \mathrm{~s}$. By activated partial thromboplastin time methanolic extract of F.auriculata leaves on haemostasis were evaluated ranged $70.3 \pm 5.5 \mathrm{sec}$ and for $\mathrm{n}$-hexane, chloroform and ethyl acetate fractions APTT values ranged from $51.7 \pm 2.4$ to $72.3 \pm 5.4,49.7 \pm 6.1$ to $71.7 \pm 5.5$ and $47.7 \pm 3.3$ to $69.7 \pm 2.9$ s, respectively 8 .

\section{Antihypoxic activity (effect of leaf extract on gsh level in blood and cardiac tissue):}

Increase in the Reactive Oxidative species(ROS) happens due to lack of oxygen supply in tissues (hypoxia), which is the cause of various hepatic diseases. Naturally, The damage caused by ROS is prevented by antioxidants present in the body. With the increase in ROS an imbalance between antioxidant and ROS occurs which is known as oxidative stress state. Glutathione (GSH) is an endogenous antioxidant which can be used as a parameter of antioxidant content in the body. The effect of leaf extract of F.auriculata on GSH level of rats heart have been investigated. The leaf extract was given to the Sprague Dawley rats for 14 days, i.e. divided into four categories $(n=8)$, normoxia and hypoxia treatment given in duration of 1,3 , and 7 days. Each group became divided into 2 categories $(n=4)$, group of excessive dosage (300 mg / KgBB) and less dosage (150 mg / KgBB) of leaf extract. Measurement of GSH levels through Ellman method. There was a decrease in heart GSH levels in both excessive and lesser dosage, however GSH ranges were higher within the high dose due to the better additional antioxidants ${ }^{38}$.

\section{Anti-inflammatory activity :}

The anti-inflammatory activity of the extracts of $F$. auriculata was evaluated on carrageenin-induced rat hind paw oedema model. The results revealed that increasing the concentrations of the extracts reduced the inflammation in a dose dependant manner. The alcoholic leaf extract at $(500 \mathrm{mg} / \mathrm{kg})$ has been found to possess significant antiinflammatory activity. anti-inflammatory activity may be mainly due to the presence of triterpenoids as betulinic acid and sterols, lupeol, stigmasterol and $\beta$-sitosterol-3-0- $\beta$-Dglucoside 23 .

Toxicity activity: Acute toxicity test of the methanolic leaf extract of Ficus auriculata was investigated. There was no behavioural change, no mortality and toxicity observed after the administration of 1000,2000 , and $3000 \mathrm{mg} / \mathrm{kg}$ concentration dose of methanolic leaf extract in mice bodies. LD50 was found at $3000 \mathrm{mg} / \mathrm{kg}$ and oral administration of the methanol leaf extract had a low toxicity[35]. So, the Overall conclusion stated that the LD50 value of the F.auriculata aqueous extract is more than 2000 $\mathrm{mg} / \mathrm{kg}$ body weight ${ }^{37}$.

\section{DISCUSSION AND CONCLUSION}

The phytochemical constituents present in leaves, fruit and stem bark of F.auriculata showed the presence of alkaloids, carbohydrates, glycosides, tannins, flavonoids, and sterols. And these phytoconstituents may be attributed to the antimicrobial, anti-inflammatory, antidiabatic, antioxidant, hepatoprotective etc. properties of a plant and could be used for the treatment of diseases caused by pathogens. Also the Ficus species can be considered as good sources of natural antioxidants for food applications. Anticancerous activity was found insignificant, but in the future at higher concentration it could be used as an anticancer drug in medical field. The antiproliferative activity against colon and liver cell lines, and it also induce apoptosis by DNA fragmentation, thus demonstrating their potentials as anticancer chemotherapeutic agents. The excellent properties of F.auriculata which were evident by a number of studies and literature above makes it a very helpful drug due to its curative properties, easily available at very low cost.

\section{REFERENCES}

1. Mahalakshmi M, Parimala M, Shoba FG. Evaluation of antidiarrhoeal potential pf methanol extract of Ficus bengalensis Linn. stem bark and root bark. Int J Pharmacogn Phytochem Res 2014; 6(3):454-458.

2. Baliga MS, Pai RJ, Bhat HP, Palatty PL, Boloor R. Chemistry and medicinal properties of the Bakul (Mimusops elengi Linn): A review. Food Res Int. 2011; 44(7):1823-9. 
3. Raghavendra MP, Prasad AD, Shyma TB. Investigations on antidiabetic medicinal plants used by tribes of Wayanad district, Kerala. Int J Pharm Sci Res. 2015; 6(8):3617.

4. Ahmad S, Bhatti FR, Khaliq FH, Irshad S, Madni A. A review on the prosperous phytochemical and pharmacological effects of Ficus carica. Int J Bioassays 2013; 2:843-849.

5. Lansky EP, Paavilainen HM, Pawlus AD, Newman RA. Ficus spp.(fig): Ethnobotany and potential as anticancer and antiinflammatory agents. J Ethnopharmacol 2008; 119(2):195-213.

6. Shi Y, Mon AM, Fu Y, Zhang Y, Wang C, Yang X, Wang Y. The genus Ficus (Moraceae) used in diet: Its plant diversity, distribution, traditional uses and ethnopharmacological importance. J Ethnopharmacol 2018; 226:185-196.

7. Ramadan MA, Ahmad AS, Nafady AM, Mansour AI. Chemical composition of the stem bark and leaves of Ficus pandurata Hance. Nat prods res, 2009; 23 (13)1218-1230.

8. Ambreen S, Tariq M, Masoud MS, Ali I, Qasim M, Mushtaq A, Ahmed M, Asghar R. Anticoagulant potential and total phenolic content of six species of the genus Ficus from Azad Kashmir, Pakistan. Trop J Pharm Res 2019; 18(6):1245-1251.

9. Zhang Z, Wang XM, Liao S, Tian HZ, Li HQ. Taxonomic treatment of the Ficus auriculata complex (Moraceae) and typification of some related names. Phytotaxa 2019; 399(3):203-208.

10. Roder W, Gyeltshen T. Ficus auriculata-its relative importance in Bhutan, farmers' preference and fodder quality. Agrofor Syst 2003; 57(1):11-17.

11. Shilpakar A, Gaire BP, Bahadur SC, Lamichhane R, Neupane S. Phytochemical Screening and analysis of antibacterial and antioxidant activity of Ficus auriculata,Lour. stem bark. Ph.D. Thesis, Pokhara University Nepal, 2009.

12. Gair BP, Lamichhane R, Sunar CB, Shilpakar A, Neupane S, Panta S.. Phytochemical screening and analysis of antibacterial and antioxidant activity of Ficus auriculata (Lour.) stem bark. Pharmacog J 2011; 3(21):49-55.

13. Kunwar RM, Bussmann RW. Ficus (Fig) species in Nepal : a review of diversity and indigenous uses. Lyon 2006; 11(1):8597.

14. Khatun MJM, Rahman MM, Rahim MA, Jakariya M, Mirdah MH. Study on the ethnobotany and nutritional status of three edible Ficus species in hill district of Bangladesh. Int J Min Fruits, Med Arom Plants 2016; 2(1):35-40.

15. George M, Joseph L, Paul MN. Ficus auriculata;a pharmacological update. Int J Curr Res Acad. Rev 2016;4:26-31.

16. Sirisha N, Srinivasulu M, Sangeeta K, Chetty CM. Antioxidant properties of Ficus species-A review. Int J Pharm Tech. Res 2010; 2(4):2174-2182.

17. Saklani S, Chandra S. In vitro antimicrobial activity, nutritional profile and phytochemical screening of wild edible fruit of Garhwal Himalaya (Ficus auriculata). Int J Pharm Sci Rev Res 2012; 12(2):61-64.

18. Kumari A, Verma R, Sharma M, Chauhan P, Kumar A. Evaluation of phytochemical, antioxidant, antibacterial and anti-cancerous activity of Ficus auriculata Lour. and Osyris wightiana Wall. ex Wight. Bull. Env. Pharmacol Life Sci 2018; 7(8):64-70.

19. Rosalind TH, Dutta BK, Paul SB.. In vitro antioxidant capacity of estimation of total phenolic and flavonoid content of Ficus auriculata Lour. Int J Pharm Pharm Sci 2012; 4(4):518-521.

20. Khayam SM, Muhammad Zhoor M, Abdul BS. Biological and phytochemical evaluation of Cotoneaster microphyllus, Ficus auriculata and Calotropis procera. Latin Am J Pharm 2019; 38(5):945-953.

21. Pande Y, Upadhyay S, Manivannan S, Sharma L, Bhatt SS. Nutraceutical potential of Ficus roxburghii an underutilized fruit of Sikkim Himalayas. J Appl Nat Sci 2018; 10(3):876-880.

22. Anjum N, Tripathi Y. In vitro alpha-amylase and alpha- glusidaseinhibitory activities of fruits of Ficus auriculata. Int Pharma Bio Sci 2019; 10(4):134-141.

23. El-Fishawy A, Zayed R, Afifi S. Phytochemical and pharmacological studies of Ficus auriculata Lour. J Nat Prod 2011; 4:184-195.

24. Qi CC, Fu YH, Chen WH, Chen GY, Dai CY, Song XP, Han CR. A new isoflavone from the roots of Ficus auriculata. Nat prod res 2018, 32(1):43-47.

25. John J, Aravindakumar CT, Thomas S. Green Synthesis of Silver Nanoparticles Using Phyto-Constituents of Ficus auriculata Lour. Leaf Extract: Mechanistic Approach. SAJ Biotechnol 2018; 4(103):19-21.

26. Shao TM, Zheng CJ, Li XB, Chen GY, Song XP, Han CR. A new12membered lactone from the stems of Ficus auriculata. Nat prod res 2018; 32(19):2268-2273.

27. Shao T, Song X, Chen G, Li X, Yao G, Deng K, Huang K. Analysis of the chemical constituents of volatile oil from the leaves of Ficus auriculata lour by GC-MS. Chemistry and Industry of Forest Products 2013; 33(3):135-137.

28. Shao TM, Zheng CJ, Han CR, Chen GY, Dai CY, Song XP, Zhang JC, Chen WH. Lactones from Ficus auriculata and their effects on the proliferation function of primary mouse osteoblasts in vitro. Bioorg Med Chem Lett 2014; 24(16):3952-3955.

29. Puangpradab R, Suksathan R, Saratan N, Puangsombat P. Antioxidant properties and nutritive values of native figs consumed in northern Thailand. J Nat Sci 2018; 1210(8):25-58.

30. Bertoletti LL, Skoronski E, Schittler L, Kempka AP.. Extracts of leaves of Ficus auriculata Lour: Antioxidant, antimicrobial and phytotoxic activity. Agric Conspec Sci 2018; 83(4):321-328.

31. Shahzad A, Ishtiaq M, Tanvee H, Waheeda M, Amin S, Azhar A Atiq $H$. Analysis of antimicrobial potential of some Ficus taxa from district Bhimber Azad Jammu and Kashmir, Pakistan. Appl Ecol Environ Res 2016; 14(5):159-176.

32. Ghani RA, Jamil EF, Shah Namna MN. The role of polyamines in anti-proliferative effect of selected Malaysian herbs in human lung adenocarcinoma cell line. J Teknol 2015; 77:137-140.

33. Jamil EF, Abdul Ghani R. Ficus auriculata (fig) Extracts Induced Cell Cycle Profile Changes and Apoptosis Through CaspaseIndependent Pathway in Human Lung Adenocarcinoma Cell LineA549. J Med Plant 2017; 3(63):57-67.

34. Putthawan P, Poeaim S, Areekul V. Cytotoxic activity and apoptotic induction of some edible Thai local plant extracts against colon and liver cancer cell lines. Trop J Pharm Res 2017; 16(12):2927-2933.

35. Rosalind T, Biman K, Satya B.Antihyperglycemic and antihyperlipidemic activity of Ficus auriculata lour. leaf extract in streptozotocin-induced diabetic mice. World J Pharm Pharm Sci 2013; 3(1):412-427.

36. Tiwari Y, Singh A, Kumar B, Kumar A. In vitro evaluation of alpha amylase activity of bark extracts of Ficus Auriculata. Int J Innov Sci Res Technol 2017; 12(2):2456-2165.

37. Doley BK, Kakoti BB. Hepatoprotective potential of Ficus auriculata and Sarcochlamys pulcherrima, two ethnomedicinal plants used by the mishing community of assam. World J Pharm Pharm Sci 2018; 15(7):913-922.

38. Limanan D, Salim M, Chen M, Halim K, Gunawan F, Susanto SA Yulianti E, Helmi RH, Ferdinal F. Protection effects of Ficus auriculata L. crude leaves extract on rat heart induced by chronic systemic hypoxia. Project, Recent Advance in Health and Biomaterials, Indonesia. 10.13140/RG.2.2.13820.49289;2019.

39. Kumar SS, Rekka R, Thankachan J, Santhosh T. Identification of aphrodisiac properties of Ficus auriculata lour. fruit extract. Eur J Biomed 2018; 5(2):454-460. 